que a psicanálise acumulou ao longo de sua história e que nos convida à sua problematização e potencialização.

Recebida em 31/3/ 04.

Aprovada em 23/ 4/ 04.

Regina Neri

reginaneri@uol.com.br
DA SUBVERSÃO DO GÊNERO À REINVENÇÃO DA POLÍTICA

Problemas de gênero: feminismo e subversão da identidade. Judith

Butler. Rio de J aneiro: Civilização

Brasileira, 2003.

\section{Simone Perel son}

Psicanalista, doutora em psicopatologia fundamental e psicanálise pela Université Paris 7

Em seu livro Problemas de gênero: feminismo e subversão da identidade, Judith Butler empreende, em primeiro lugar, uma genealogia crítica, fortemente fundamentada no pensamento de Foucault, das categorias de gênero estabelecidas como uma relação binária homem-mulher. Irá demonstrar que o binarismo é um produto reificado de práticas discursivas múltiplas e difusas que funcionam como regimes de poder, sendo o falocentrismo e a heterossexualidade compulsória apontados como os elementos definidores desta produção/ construção.

A geneal ogia crítica do binarismo dos gêneros conduzirá a autora à crítica da distinção sexo-gênero, à idéia de um sexo natural ou pré-discursivo, por um lado, e um gênero culturalmente construído, por outro. A construção do caráter natural do sexo, a produção da natureza sexuada como anterior à cultura é, de fato, uma maneira de assegurar a manutenção da estrutura binária dos gêneros. Vale observar, como nota Butler, que o discurso que opõe 0 sexo natural ao gênero cultural concebe de modo habitual que a natureza é feminina e precisa ser subordinada pela cultura, invariavelmente concebida como masculina. A crítica de Butler à idéia de um sexo natural fundamenta-se na crítica de Foucault à concepção da cultura como efeito de uma lei repressiva, na qual 
encontraríamos, de um lado, uma sexualidade subversiva ou emancipatória, livre da lei, do discurso e do poder (podendo esta ser feminina ou não) e, de outro lado, a lei repressora.

Pelo contrário, sexualidade e poder são co-extensivos e a concepção de um desejo como original ou recalcado é um efeito da própria lei coercitiva. É neste sentido que Foucault afirmará que a lei é produtiva: ela produz a ilusão da distinção entre predisposições primárias naturais e livres e disposições secundárias legitimadas pela lei. Como efeito destas três críticas, será a própria noção de uma identidade como fundamentada na divisão do gênero e, mais ainda, como fundamento do gênero que será colocada em causa.

Segundo Butler, o eu de gênero permanente define-se por um estilo, por atos repetidos que constroem a ficção de uma identidade substancial. Neste sentido, não há identidade de gênero por trás das expressões do gênero; os atributos do gênero não são expressivos mas performáticos, isto é, constituintes da identidade que pretensamente revelam.

Mas, face à inexistência de toda e qualquer exterioridade com relação ao gênero construído, como é possível subvertêlo? Como é possível subverter a lei? Esta é a questão que interessa de fato à autora, pois o livro de Butler é antes de tudo um projeto político, e mais ainda um projeto de formulação de estratégias sustentadas, e não ideais, de subversão do gênero.

Em primeiro lugar, a autora mostrará que não se deve compreender a hegemonia do poder como o fracasso da possibilidade de subversão, pois operar no interior da matriz do poder não é o mesmo que reproduzir acriticamente as relações de dominação. Além disso, a afirmação de que a sexualidade, assim como a identidade e o gênero, são construções cultu- rais, não deve ser compreendida como a afirmação de seu caráter ilusório ou artificial - compreensão resultante da postulação de um binário que opõe real a autêntico. Mas sobretudo o que deve ser considerada é a possibilidade de que a enunciação de um sexo ou de uma sexualidade anterior ao próprio enunciado contradiga performativamente a si mesma, gerando alternativas em seu lugar, isto é, criando de maneira inadvertida as condições de sua própria substituição cultural.

Antes de explicitar o modo segundo o qual é possível, neste contexto, a produção de práticas efetivas de subversão, Judith Butler propõe uma análise crítica de algumas formulações teóricas nas quais uma estratégia de subversão do gênero estaria em ação, de modo a indicar os limites de cada uma delas. Para empreender esta tarefa, a autora abordará sobretudo al gumas formulações de LéviStrauss, Lacan, Freud, Foucault, Kristeva e Monique Wittig.

Das formulações de Lévi-Strauss, Butler critica a oposição natureza-cultura o que o levaria a "ontologizar" o sexo. Embora "desontologize" o "ser" do gênero e/ ou sexo, Lacan mostra-se ideologicamente suspeito quando, ao invés de radicalizar a dimensão cômica da ontologia sexual por ele apontada, desenvolve uma idealização religiosa do fracasso. Freud, por sua vez, amplia a noção de predisposições libidinais primárias, sendo quem de fato produz a ficção lingüística do desejo recalcado e a idéia de que a entrada no campo cultural desvia o desejo do seu significado original. Kristeva, embora estabeleça uma produção cultural - a poesia - como o campo de subversão da lei paterna, ao conceber esta subversão como a manifestação no discurso poético da multiplicidade e do caos 
libidinal próprios ao relacionamento primário com o corpo materno, naturaliza o corpo e faz do ato subversivo a manifestação de uma realidade pré-cultural.

0 Foucault que Butler critica é aquele que, em sua introdução ao diário do hermafrodita Herculine, contradiria a si mesmo ao demonstrar, através da sua compreensão do suposto desaparecimento do sexo de Herculine como o lugar de um limbo feliz de uma não-identidade, um deleite sentimental e um ideal emancipatório difícil de manter. Embora, enfim, a literatura de Wittig, ao seguir uma trajetória narrativa de desintegração, revele a contingência do gênero, a autora mantém a pressuposição da condição universal do sujeito, sustentando que este tem uma integridade pré-social e anterior a seus traços de gênero.

A partir da explicitação dos limites de cada uma destas estratégias subversivas, Butler pode, enfim, esclarecer no que consiste o que ela considera uma estratégia política capaz de subverter as noções naturalizadas do gênero e a ilusão daidentidade fundadora. Em primeiro lugar, muito mais do que manifestar um repúdio radical de uma sexualidade construída, as práticas efetivamente subversivas são aquelas que, ao produzirem uma descontinuidade e uma dissonância subversiva entre sexo, gênero e desejo, questionam suas supostas relações e nos permitem desconstruir a aparência substantiva do gênero e da identidade. Em segundo lugar, o meio eficaz para esta desconstrução se encontra nas deformações ou repetições parodísticas - nas performances dissonantes e desnaturalizadas que revelam que 0 original nada mais é do que uma paródia da idéia do original e do natural. Em terceiro lugar, os atos políticos são atos que subvertem a partir de dentro dos termos da lei, revelando, não o interior recalcado ou a base oculta da cultura, mas sobretudo uma outra versão dela própria, versão que surge quando a cultura se vira contra si mesma e gera metamorfoses inesperadas. Enfim, para que haja uma ação política não é necessário supormos a existência prévia de uma identidade, sede dos interesses políticos pelos quais se luta. Pelo contrário, o eu constrói-se performativamente através de sua ação; ele é uma prática, e sobretudo uma prática discursiva.

Nestes tempos do "fim da política", Butler nos oferece não apenas um livro de extremo rigor teórico, indicando de modo preciso de que modo são naturalizadas e reificadas noções construídas culturalmente, como também aponta uma nova direção, renovando 0 ânimo que tem nos faltado, para retornarmos ao campo hoje tão desprezado da ação política.

Recebida em 3/ 5/ 04.

Aprovada em 20/ 5/ 04.

Simone Perelson

Rua Humberto de Campos 974/ 1602

22430190 Rio de Janeiro RJ

Telefax (21) 32041696

perelbell@aol.com 